\title{
PENINGKATAN KETERAMPILAN MOTORIK KASAR ANAK USIA 4-5 TAHUN \\ MELALUI PERMAINAN TRADISIONAL TAMBI-TAMBIAN PENELITIAN TINDAKAN PADA KELOMPOK A DI TK NASIONAL KPS \\ BALIKPAPAN TAHUN 2018
}

\author{
IIS VERAWATI \\ PAUD PPs Universitas Negeri Jakarta \\ e-mail: iissimatupang@gmail.com
}

\begin{abstract}
Abstrak
Tujuan dari penelitian ini adalah untuk meningkatkan keterampilan motorik kasar anak melalui permainan tradisional “Tambi-tambian”. Permainan tradisional sangat bermanfaat bagi perkembangan dasar anak dan melaluinya anak-anak dapat mengenali dan melestarikan budaya lokal. Penelitian ini dilakukan pada 11 anak dari kelompok A di TK Nasional KPS Balikpapan. Prosedur untuk penelitian tindakan ini menggunakan model Kemmis dan McTaggart melalui empat tahap: perencanaa, tindakan dan pengamatan, refleksi. Pengumpulan data menggunakan wawancara, observasi, dan dokumentasi. Analisis data dilakukan menggunakan analisis kuantitatif dan kualitatif. Hasil penelitian menunjukkan peningkatan keterampilan motorik kasar melalui permainan tradisional "Tambi-tambian”. Pra tindakan, keterampilan motorik kasar anak adalah 53,41\%, setelah dilakukan tindakan keterampilan motorik kasar anak meningkat pada siklus I adalah 68,86\%, dan siklus II adalah 81,59\%. Permainan tradisional “Tambi-tambian” berkontribusi untuk meningkatkan keterampilan motorik kasar anak.
\end{abstract}

Kata Kunci: keterampilan motorik kasar, permainan tradisional, anak usia 4-5 tahun

\begin{abstract}
The aim of this research is to enhance the children's gross motor skill through traditional games “Tambi-tambian”. Traditional games are very useful for the basic development of children and through it children recognize and preserving local culture. The research was conducted among 11 children of group A at TK Nasional KPS Balikpapan. The procedures for this action research using Kemmis and McTaggart's model through four stages: planning, action and observation, reflection. The data were collected using interview, observation, and documentation. Data analysis is carried using both quantitative and qualitative analysis. The results of research show enhancement of gross motor skill through traditional games “Tambi-tambian”. Pre-intervensi, children's gross motor skill is 53,41\%, after the conducted action children's gross motor skill increasing in the $1^{\text {st }}$ cycle is $68,86 \%$ and $2^{\text {nd }}$ cycle is $81,59 \%$. Traditional games "Tambi-tambian" contributes to enhance children's gross motor skill.
\end{abstract}

Keywords: gross motor skill, traditional games, children age 4-5 years

\begin{tabular}{ccl}
\hline \hline $\begin{array}{c}\text { PENDAHULUAN } \\
\text { Indonesia }\end{array}$ & $\begin{array}{l}\text { dilestarikan oleh masyarakat dengan } \\
\text { cara mewariskan kebudayaan dari }\end{array}$ \\
$\begin{array}{c}\text { keanekaragaman } \\
\text { adalah identitas diri dari suatu bangsa }\end{array}$ & $\begin{array}{l}\text { gudaya } \\
\text { generasi tua ke generasi muda melalui }\end{array}$ \\
pendidikan.
\end{tabular}


Keanekaragaman budaya di Indonesia salah satunya adalah permainan tradisional. Indonesia memiliki berbagai macam permainan tradisional, pada setiap daerah memiliki kekhasannya masing-masing. Di Kalimantan Timur terdapat berbagai macam permainan seperti Belogo, Begasing, Sembunyi-sembunyian Batu, Begulik, Belepuk, Beluncur, Batu Lele, Sesarungan, Bahempas, Bebidukan, Tambi-tambian, Ampar-ampar Pisang, Lamusi, Asinan, Apollo, Lompat Karet, Chinaboy dan Selodor (Hamzuri \& Siregar, 1998: 355-374). Pada penelitian ini, peneliti menerapkan permainan tradisional Tambi-tambian sebagai media pembelajaran untuk meningkatkan keterampilan motorik kasar anak.

Ismatul Khasanah, Agung Prasetyo, dan Ellya Rakhmawati telah melakukan penelitian dengan menggunakan lima permainan tradisional khas Jawa Tengah pada anak-anak berusia 4-6 tahun. Hasilnya adalah kelima permainan tradisional tersebut merupakan sarana dalam mengembangkan aspek perkembangan dasar anak seperti fisik-motorik, sosialemosi, kognitif, dan bahasa. Terlebih lagi anak usia dini dapat mengenal nilai-nilai budaya lokal yang terdapat dalam setiap jenis permainan (Khasanah, Prasetyo dan Rakhmawati, 2011: 91-105).

Penelitian lain yang sebelumnya dilakukan oleh Ting Liu, Michelle Hamilton, dan Sean Smith menyatakan bahwa:

“(...) gross motor skills are shown to help with skill development, physical activity, and healthy life style. (...) gross motor delays are often attributed to lack of instruction, experience, feedback and opportunity. This delay could negatively impact their academic performance, physical activity, and health-related fitness later in life"(Liu, Hamilton, dan Smith, 2015: 14).

Dalam bentuk alih bahasa, bahwa keterampilan motorik kasar anak ditujukan untuk membantu pengembangan keterampilannya, aktivitas fisik, dan gaya hidup sehat. (...) keterlambatan motorik kasar sering dikaitkan dengan kurangnya pengajaran, pengalaman, respon dan kesempatan. Keterlambatan ini dapat berdampak negatif pada kinerja akademis, aktivitas fisik, dan kebugaran terkait kesehatan di kemudian hari.

Usia anak 0-8 tahun adalah usia yang tepat bagi anak untuk diberikan stimulasi sejak usia dini, sehingga aspek-aspek perkembangan anak dapat berkembang secara optimal dan anak memiliki kesiapan dalam memasuki pendidikan selanjutnya. Hurlock (dalam Meitasari Tjandrasa dan Muslichah Zarkasih) menyatakan bahwa usia dini (0-8 tahun) adalah usia yang ideal untuk anak mempelajari keterampilan motorik, karena pada usia ini: 1) tubuh anak lebih lentur; 2) belum banyak memiliki keterampilan yang akan berbenturan dengan keterampilan yang baru dipelajarinya; 3) berani mencoba sesuatu yang baru; 4) bersedia mengulangi suatu tindakan hingga otot terlatih untuk melakukannya secara efektif; 5) memiliki waktu yang lebih banyak untuk belajar menguasai keterampilan (Hurlock, 1978: 156).

Keterampilan motorik kasar menurut William (dalam Zawi, Lian, dan Abdullah) menyatakan bahwa, "gross motor skill refers to the ability to use major muscles groups to perform organized joint movements 
like walking, running, throwing, jumping, climbing and catching” (Zawi, Lian, Abdullah, 2014: 242-252). Menurut William, keterampilan motorik kasar adalah kemampuan untuk menggunakan kelompok otot utama untuk melakukan gerakan sendi yang teratur. Gallahue (2006: 17) menyatakan bahwa, "gross motor skills use several large muscle to perform a movement task (running, jumping, throwing, catching)". Dalam bentuk alih bahwa bahwa keterampilan motorik kasar menggunakan otot-otot besar untuk melakukan gerakan seperti berlari, melompat, melempar dan menangkap. Diane E. Papalia, Sally Wendkos Old, dan Ruth Duskin Feldman (dalam A. K. Anwar) juga menyatakan bahwa keterampilan motorik kasar adalah keterampilan fisik yang melibatkan otot-otot yang besar (Papalia, Old, dan Feldman, 2008: 186). Gallahue (2006:48-49) mengemukakan ada tiga aspek dalam keterampilan motorik kasar, yaitu: 1) lokomotor, yaitu gerakan yang melibatkan perubahan lokasi tubuh, karena tubuh bergerak dari satu tempat ke tempat lainnya di atas permukaan tanah seperti berjalan, berlari, melompat, meloncat, meluncur, dan berjingkrak; 2) non-lokomotor, yaitu setiap pergerakan dengan posisi untuk mendapatkan dan mempertahankan keseimbangan seseorang yang berhubungan dengan gaya gravitasi. Misalnya saja seperti: menghindari, mencapai, berputar, memutar; 3) manipulatif, yaitu gerakan yang memberi kekuatan atau menerima kekuatan dari objek, seperti melempar, menangkap, menendang dan memukul benda.

Berdasarkan uraian di atas tentang keterampilan motorik kasar, maka keterampilan motorik kasar adalah kemampuan menggunakan otot- otot besar untuk dapat melakukan gerakan dasar, seperti gerakan lokomotor, gerakan non-lokomotor dan gerakan manipulatif.

Hurlock (1978: 156-157)

menyatakan ada delapan hal penting dalam mempelajari keterampilan motorik, yaitu: 1) kesiapan belajar; 2) kesempatan belajar; 3) kesempatan berpraktek; 4) model yang baik; 5) bimbingan; 6) motivasi; 7) setiap keterampilan motorik harus dipelajari secara individu; 8) keterampilan sebaiknya dipelajari satu demi satu. Davc (dalam Richard Decaprio) mengemukakan lima kategori titik tekan yang bisa diklasifikasikan dalam kegiatan pembelajaran motorik bagi anak, yaitu peniruan, manipulasi, ketelitian, artikulasi dan pengalamiahan (Decaprio, 2013: 55-61). Tahap pertama, peniruan (imitation). Anak meniru semua keterampilan atau gerakan motorik yang dicontohkan dengan baik dan benar, meskipun peniruan yang dilakukan anak masih dalam bentuk global dan tidak sempurna. Tahap kedua manipulasi (penggunaan konsep). Pendidik memberikan pengarahan dan anak mengikuti petunjuk yang diberikan. Tahap ketiga ketelitian. Pada tahap ini pendidik harus mencermati setiap sikap dan tindakan motorik yang dilakukan anak berlangsung dengan proporsi. Tahap keempat artikulasi (articulation). Artikulasi berarti perangkaian, tahap ini adalah upaya guru untuk menekankan koordinasi suatu rangkaian kegiatan motorik atau keterampilan motorik dengan membuat urutan yang tepat dan mencapai sesuatu (hasil) yang diharapkan. Tahap kelima pengalamiahan (naturalization). Pengalamiahan adalah kemampuan tertinggi dalam pembelajaran motorik. Tahap ini, menuntut pendidik menjadikan semua keterampilan 
motorik yang diajarkan menjadi kebiasaan anak, atau menjadi keterampilan yang natural dalam diri mereka.

Berdasarkan uraian di atas, maka strategi yang tepat untuk meningkatkan keterampilan motorik kasar anak adalah memberikan contoh, memberikan pengarahan atau petunjuk, memperbaiki gerakan anak yang salah, merangkai keterampilan yang sudah dipelajari dengan keterampilan lainnya dan secara alami anak terbiasa melakukan keterampilan motorik tersebut.

Montessori (dalam Suyadi dan Maulidya Ulfah) menyatakan bahwa:

"For the child, play is enjoyable, voluntary, purposeful, and spontaneously choosen activity. it is often creative as well involve problem solving, leaning new social skill, new language and new phsysical skill” (Suyadi dan Ulfah, 2015: 34).

Montessori menyatakan bahwa bagi anak bermain itu menyenangkan, sukarela atau tanpa paksaan, penuh arti, dan aktivitas spontan. Permainan memerlukan kreatif untuk menyelesaikan masalah, belajar keterampilan sosial baru, bahasa baru dan keterampilan fisik yang baru. Mayesty (dalam Yuliani Sujiono) mengatakan bahwa bagi anak bermain adalah kegiatan yang mereka lakukan sepanjang hari karena bagi anak bermain adalah hidup dan hidup adalah permainan (Sujiono, 2012: 86). James Sully (dalam Mayke S. Tedjasaputra) menyatakan bahwa tertawa adalah tanda dari kegiatan bermain dan tertawa ada di dalam aktivitas sosial yang dilakukan bersama sekelompok teman (Tedjasaputra, 2005: 15).
Berdasarkan uraian di atas tentang bermain, maka bermain merupakan cara alamiah anak untuk mempelajari dan belajar banyak hal sehingga semua aktivitasnya dimulai dan diakhiri dengan bermain yang ditandai dengan tertawa karena rasa senang.

Parten (dalam Mayke S. Tedjasaputra) mengemukakan enam tahapan perkembangan bermain pada anak yang tampil berurutan:

1. Unoccupied Play

Tahap ini anak tidak benarbenar terlibat dalam kegiatan bermain, anak hanya mengamati kejadian yang menarik di sekitarnya.

2. Solitary Play (Bermain Sendiri)

Ciri anak pada tahap ini adalah anak bersifat egosentris, tidak berusaha untuk berinteraksi dengan anak lain dan hanya tertarik pada diri sendiri dan kegiatannya sendiri.

3. Onlooker Play (Pengamat)

Pada umumnya tahap ini berlangsung bagi anak usia dua tahun. Anak mengamati anak-anak lain melakukan kegiatan bermain, dan anak berminat terhadap kegiatan anak lain yang diamatinya.

4. Paralel Play (Bermain Paralel)

Anak bermain dengan anak lain dengan melakukan kegiatan yang sama, secara sendiri-sendiri pada saat yang bersamaan, namun tidak ada interaksi diantara mereka.

5. Assosiative Play (Bermain Asosiatif)

Bermain asosiatif ditandai dengan adanya interaksi dan mau saling bertukar permainan, namun masingmasing anak tidak terlibat dalam kerja sama.
6. Cooperative Play (Bermain Bersama)
Bermain bersama ditandai dengan adanya kerjasama atau pembagian tugas dan pembagian peran 
antara anak-anak yang terlibat dalam permainan untuk mencapai satu tujuan tertentu (Tedjasaputra,2005:21-24). Berdasarkan teori Parten, maka anak usia 4-5 tahun berada pada tahap bermain bersama (Cooperative Play).

James Danandja (dalam Keen Achroni) menyatakan bahwa permainan tradisional adalah salah satu bentuk yang berupa permainan anak-anak. yang beredar secara lisan di antara anggotaanggota kolektif tertentu, berbentuk tradisional dan diwarisi turun-temurun, serta banyak mempunyai variasi (Archoni, 2012: 45). Menurut Madetaro (dalam Andika Tiyas Apriliawati) permainan tradisional adalah aktivitas budaya yang terdiri dari unsur-unsur gerak, seni, nilai lokal, dan budaya yang tersebar di dalam masyarakat. Permainan tradisional ini sejalan dengan tujuan pendidikan yaitu memacu pertumbuhan dan perkembangan jasmani, mental, emosional, dan sosial budaya yang selaras dalam upaya pembentukan serta mengembangkan kemampuan dan keperibadian yang berwawasan lingkungan (Apriliawati, 2016: 524). Akbari et. al. (2009: 124) juga menyatakan bahwa "Traditional games have humanity and cultural values, beliefs translate by these from one lineage to other". Menurut Akbari et. al. permainan tradisional memiliki nilai kemanusian dan budaya, keyakinan yang diteruskan dari generasi satu ke generasi selanjutnya.

Berdasarkan uraian di atas, maka permainan tradisional adalah kegiatan menyenangkan yang dimainkan pada daerah tertentu yang beredar secara lisan di antara anggotaanggota masyarakat tertentu yang mengandung nilai-nilai budaya, berbentuk tradisional dan diwarisi turun-temurun, memiliki banyak variasi dan dapat memberikan rasa puas atau senang bagi si pelaku serta memacu pertumbuhan dan perkembangan anak.

Penelitian ini bertujuan untuk:

1. Mengetahui proses pembelajaran melalui permainan tradisional Tambi-tambian dalam meningkatkan keterampilan motorik kasar anak usia 4-5 tahun pada kelompok A di TK Nasional KPS Balikpapan.

2. Mengetahui hasil permainan tradisional Tambi-tambian dalam meningkatkan keterampilan motorik kasar anak usia 4-5 tahun pada kelompok A di TK Nasional KPS Balikpapan

\section{METODE}

Metode penelitian yang digunakan dalam penelitian ini adalah penelitian tindakan (Action Research). Peneliti menggunakan desain model Kemmis dan McTaggart dimulai dari perencanaan (planning), pelaksanaan tindakan (acting) dan pengamatan (observation), serta refleksi (reflecting), dan perencanaan kembali (Sudaryono, 2014: 168). Penelitian ini melibatkan 11 anak pada kelompok A di TK Nasional KPS Balikpapan. Teknik analisis data yang digunakan dalam penelitian ini adalah kuantitatif deskriptif dan analisis data secara kualitatif.

\section{HASIL DAN PEMBAHASAN}

Pada penelitian ini keterampilan motorik kasar anak usia 4-5 tahun ditingkatkan melalui permainan tradisional Tambi-tambian. Permainan Tambi-tambian adalah permainan tradisional khas kota Balikpapan.

Dalam penelitian ini terdapat peningkatan keterampilan motorik kasar anak di berbagai aspek, diantaranya aspek lokomotor, yaitu seperti berjalan sampai di garis pelempar, berlari dengan cepat ketika mengejar lawan 
pemain, dan berlari dengan cepat sambil menghindari lemparan bola dari lawan pemain; aspek non-lokomotor, yaitu seperti berdiri di belakang garis pelempar, membungkukan badan untuk mengambil bola, dan menghindari lemparan bola dari lawan pemain dengan mengubah arah tubuh; dan aspek manipulatif seperti menggelindingkan bola sampai masuk lubang dengan satu tangan di antara kedua kaki, menggelindingkan bola sampai masuk ke dalam lubang dengan satu tangan melalui samping badan, menangkap bola yang menggelinding dari medan datar dengan tepat, dan melempar bola tepat pada sasaran. Melalui contoh dari guru, motivasi, bimbingan, dan memberikan kesempatan anak untuk mempraktekkan, maka terlihat aspek lokomotor, non-lokomotor, dan manipulatif anak mengalami peningkatan melalui penerapan permainan tradisional Tambi-tambian.

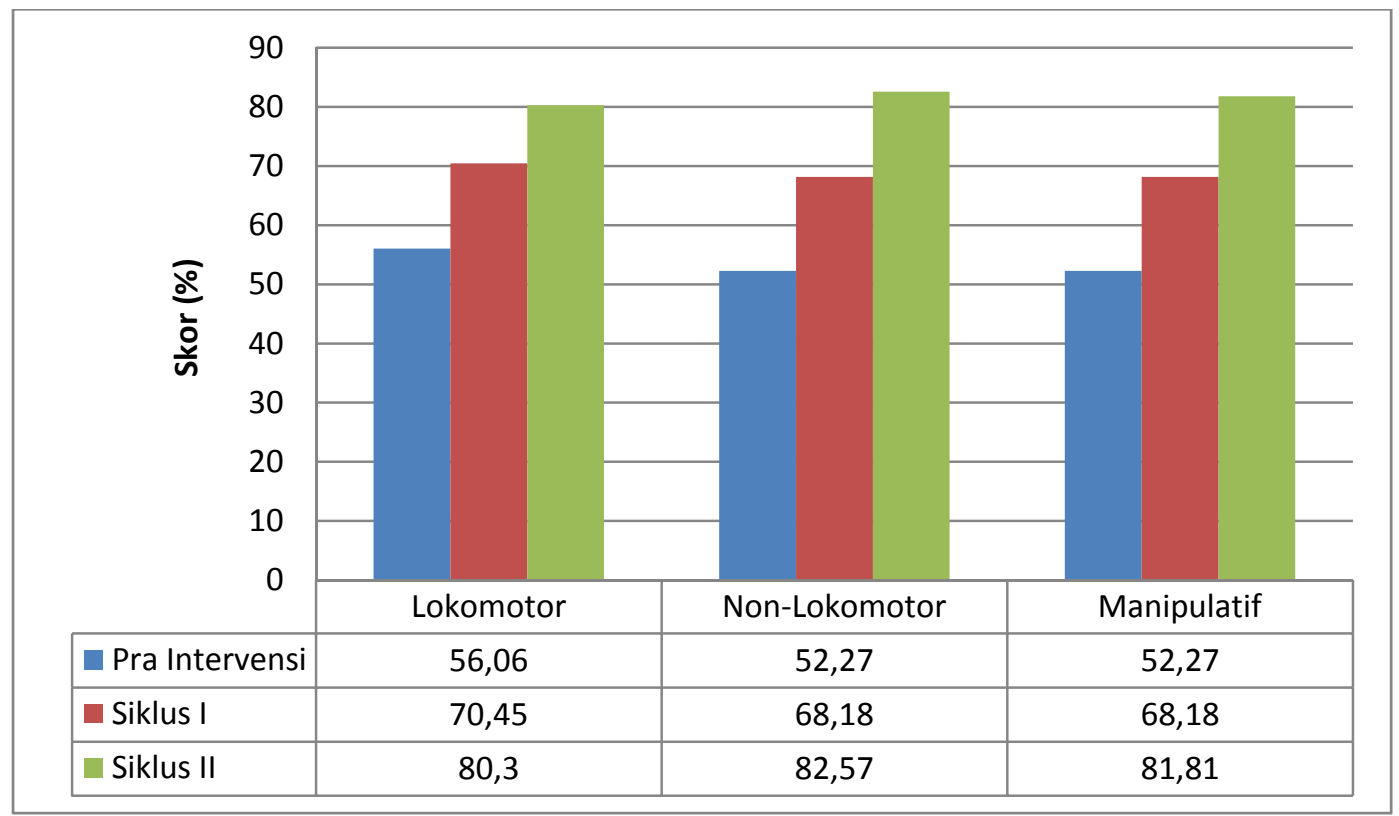

Grafik 1

Keterampilan Motorik Kasar Pra Intervensi, Siklus I, dan Siklus II Berdasarkan aspek Lokomotor, Non-Lokomotor, dan Manipulatif

Tabel 1

Data Hasil Peningkatan Motorik Kasar Anak

Pada Pra Intervensi, Siklus I dan Siklus II

\begin{tabular}{|c|c|c|c|c|c|c|c|}
\hline \multirow{2}{*}{ No. } & \multirow{2}{*}{$\begin{array}{c}\text { Nama } \\
\text { Anak }\end{array}$} & \multicolumn{2}{|c|}{ Pra Intervensi } & \multicolumn{2}{c|}{ Siklus I } & \multicolumn{2}{c|}{ Siklus II } \\
\cline { 3 - 8 } & Skor & $\mathbf{( \% )}$ & Skor & $\mathbf{( \% )}$ & Skor & $\mathbf{( \% )}$ \\
\hline 1. & ADS & 27 & $67,5 \%$ & 32 & $80 \%$ & 36 & $90 \%$ \\
\hline 2. & DLNM & 20 & $50 \%$ & 28 & $70 \%$ & 30 & $75 \%$ \\
\hline 3. & EAS & 20 & $50 \%$ & 21 & $52,5 \%$ & 28 & $70 \%$ \\
\hline 4. & JsP & 20 & $50 \%$ & 29 & $72,5 \%$ & 34 & $85 \%$ \\
\hline 5. & JERU & 24 & $60 \%$ & 33 & $82,5 \%$ & 35 & $87,5 \%$ \\
\hline 6. & JvP & 20 & $50 \%$ & 26 & $65 \%$ & 34 & $85 \%$ \\
\hline 7. & JMS & 20 & $50 \%$ & 25 & $62,5 \%$ & 33 & $82,5 \%$ \\
\hline 8. & MNJ & 21 & $52,5 \%$ & 28 & $70 \%$ & 32 & $80 \%$ \\
\hline
\end{tabular}




\begin{tabular}{|c|c|c|c|c|c|c|c|}
\hline 9. & MFC & 22 & $55 \%$ & 29 & $72,5 \%$ & 34 & $85 \%$ \\
\hline 10. & NKACM & 20 & $50 \%$ & 24 & $60 \%$ & 31 & $77,5 \%$ \\
\hline 11. & PAI & 21 & $52,5 \%$ & 28 & $70 \%$ & 32 & $80 \%$ \\
\hline \multicolumn{2}{|l|}{ Rata-rata Kelas } & $\mathbf{2 1 , 3 6}$ & $\mathbf{5 3 , 4 1} \%$ & $\mathbf{2 7 , 5 4}$ & $\mathbf{6 8 , 8 6 \%}$ & $\mathbf{3 2 , 6 4}$ & $\mathbf{8 1 , 5 9 \%}$ \\
\hline
\end{tabular}

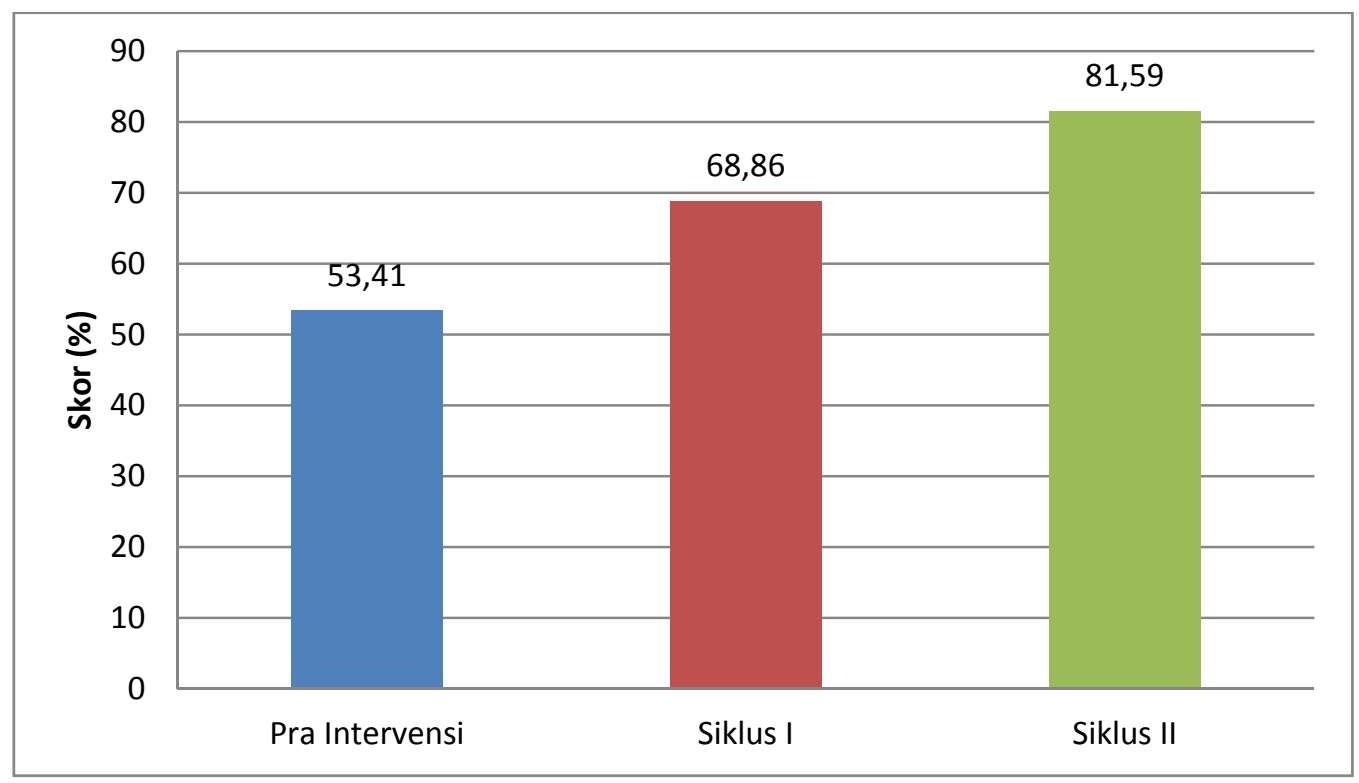

\section{Grafik 2}

Hasil Penilaian Keterampilan Motorik Kasar

Berdasarkan hasil analisis yang telah dilakukan menunjukkan bahwa adanya peningkatan rata-rata tingkat capaian perkembangan keterampilan motorik kasar anak pada kelompok A di TK Nasional KPS Balikpapan, yaitu dari pra intervensi sebesar 21,36 atau 53,41\% mengalami peningkatan pada siklus I sebesar 6,18 atau $15,45 \%$ dengan rata-rata kelas mencapai 27,54 atau 68,86\%. Selanjutnya dari siklus I ke siklus II mengalami peningkatan mencapai 5,1 atau $12,73 \%$ dengan rata-rata kelas mencapai 32,64 atau $81,59 \%$ pada kategori berkembang sesuai harapan.

Berdasarkan kesepakatan antara peneliti dengan kolabolator bahwa penelitian dikatakan berhasil jika 71\% dari jumlah anak atau 8 dari 11 anak mencapai 75\% TCP maksimal atau sebesar 30. Dari hasil pengamatan yang dilakukan anak pada siklus I, TCP anak secara keseluruhan belum mencapai TCP maksimal sebesar 30, sehingga penelitian dilanjutkan pada siklus selanjutnya. Pada siklus II nilai rata-rata capaian perkembangan yaitu sebesar 32,64 yang berada pada kategori berkembang sesuai harapan. Terdapat 10 orang anak yang mencapai TCP minimal yaitu 30, dengan begitu penelitian ini dikatakan berhasil.

\section{KESIMPULAN}

Proses pembelajaran melalui permainan tradisional Tambi-tambian telah dilaksanakan dengan baik oleh peneliti dan kolabolator di TK Nasional KPS Balikpapan. Guru memberikan bimbingan, motivasi, pengarahan, melatih satu gerakan satu demi satu secara bertahap serta mengulang-ulang gerakan yang belum dikuasai anak sehingga anak terbiasa untuk melakukannya. Kegiatan ini dilakukan sebanyak 2 siklus, siklus I sebanyak 6 kali pertemuan dan siklus II sebanyak 6 kali pertemuan. Guru mempersiapkan Rencana Kegiatan Harian, mengkomunikasikan dan 
menetapkan jadwal kegiatan, mempersiapkan lembar observasi anak, dan mempersiapkan alat dan media yang digunakan pada saat pembelajaran. Sebelum memulai kegiatan anak melakukan pemanasan, lalu guru mengenalkan permainan tradisional Tambi-tambian, menjelaskan aturan dan prosedur bermain, dan memberikan kesempatan kepada anak untuk melakukan permainan ini. Guru akan memberikan pengarahan, motivasi dan bimbingan kepada anak ketika melakukan berbagai gerak seperti berjalan, berlari, berdiri, membungkukan badan, menghindari lemparan bola, menggelindingkan bola dengan satu tangan di antara kaki dan di samping badan, menangkap bola dan melempar bola kepada lawan pemain. Setelah waktu bermain selesai, guru akan menanyakan kesan anak ketika bermain.

Keterampilan motorik kasar anak usia 4-5 tahun pada kelompok A di TK Nasional KPS Balikpapan melalui permainan tradisional Tambi-tambian menunjukkan adanya peningkatan ratarata tingkat capaian perkembangan keterampilan motorik kasar dari pra intervensi sebesar 21,36 atau 53,41\% mengalami peningkatan pada siklus I sebesar 6,18 atau $15,45 \%$ dengan rata-rata kelas mencapai 27,54 atau $68,86 \%$. Selanjutnya dari siklus I ke siklus II mengalami peningkatan mencapai 5,1 atau $12,73 \%$ dengan rata-rata kelas mencapai 32,64 atau $81,59 \%$ dengan kategori berkembang sesuai harapan. $71 \%$ dari jumlah anak atau 8 dari 11 anak telah mencapai $75 \%$ TCP maksimal atau sebesar 30 (10 orang anak yang mencapai TCP minimal yaitu 30) dengan begitu penelitian ini dikatakan berhasil.

Berdasarkan simpulan dan penelitian ini, maka peneliti mengajukan beberapa saran sebagai berikut: 1) guru dapat menyesuaikan permainan tradisional lainnya dengan tahapan perkembangan bermain anak yang ada di budaya setempat untuk meningkatkan perkembangan anak yang ingin guru tingkatkan atau perbaiki; 2) orang tua, memberikan stimulasi kepada anak dengan seimbang, baik perkembangan akademis, perkembangan motorik maupun perkembangan anak lainnya. Peningkatan motorik kasar anak dapat dilakukan orang tua bersama anak di rumah dengan bermain permainan tradisional yang dimainkan di sekolah atau mengenalkan sekaligus bermain permainan tradisional lainnya.

\section{DAFTAR PUSTAKA}

Achroni, Keen. Mengoptimalkan Tumbuh Kembang Anak Melalui Permainan Tradisional. Jogjakarta: Javalitera, 2012.

Akbari, H., Abdoli, B., Shafizadeh, M., Khalaji, H., Hajihosseini, S., Ziaee, V. (2009, Juni). The Effect of Traditional Games in Fundamental Motor Skill Development in 7-9 Years-Old Boys. Iran Journal of Pediatrics 19(2). 123-129. Retrieved from http://www.bioline.org.br/pdf?pe0 $\underline{9019}$.

Apriliawati, A. T. (2016). Penerapan Permainan Tradisional dalam Pembelajaran Pendidikan Jasmani, Olahraga, Kesehatan, Terhadap Kemampuan Motorik Siswa. Jurnal Pendidikan Olahraga dan Kesehatan 4(2). 522-528. Retrieved from http://jurnalmahasiswa.unesa.ac.id /index.php/jurnal-pendidikanjasmani/article/download/19559/1 7877/ISSN: 2338-798X

Decaprio, Richard. Aplikasi Teori Pembelajaran Motorik Di Sekolah. Jogjakarta, DIVA Press, 2013. 
Gallahue, David L dan John C. Ozmun. Understanding Motor Development Infant, Children, Adolescents, Adults Sixth Edition. America: Mc Graw Hill, 2006.

Hamzuri dan Tiarma Rita Siregar. Permainan Tradisional Indonesia. Jakarta: Direktorat Permuseuman dan Museum Negeri Provinsi seluruh Indonesia, 1998.

Hurlock, Elizabeth B. Perkembangan Anak Jilid I Edisi Keenam, terjemahan Meitasari Tjandrasa dan Muslichah Zarkasih. Jakarta: Erlangga. 1978.

Khasanah, I., Prasetyo, A., dan Rakhmawati, E. (2011). Permainan Tradisional Sebagai Media Stimulasi Aspek Perkembangan Anak Usia Dini. Jurnal Penelitian PAUDIA, 1(1), 91-105. doi: http://dx.doi.org/10.26877/paudia. v1i1.261

Liu, T., Hamilton, M., dan Smith, S. (2015, April). Motor Proficiency of The Head Start and Typically Developing Children on MABC-2. Journal of Child \& Adolescent Behavior, 3(2), 1-4. doi: 10.4172/2375-4494.1000198

Papalia, Diane E, Sally Wendkos Old, dan Ruth Duskin Feldman. Human Development Edisi Kesembilan, terjemahan A. K. Anwar. Jakarta: Prenadanedia Group, 2008.

Sudaryono. Classroom Action Research Teori dan Praktek Penelitian Tindakan Kelas. Jakarta: Lentera Ilmu Cendekia, 2014.
Sujiono, Yuliani Nurani. Konsep Dasar Pendidikan Anak Usia Dini. Jakarta: Indeks, 2012.

Suyadi dan Maulidya Ulfah. Konsep Dasar Paud. Bandung: PT. Remaja Rosdakarya, 2015.

Tedjasaputra, Mayke S. Bermain,Mainan dan Permainan. Jakarta: Grasindo, 2005.

Zawi, K., Lian, D. K. C., Abdullah, R. T. (2014). Gross Motor Development of Malayasian Hearing Impaired Male Pre and Early School Children. International Education Studies $7(13)$. http://dx.doi.org10.5539/ies.v7n1 3p242 